\title{
Labyrinty slovanského baroka
}

\author{
Ivo Pospíšil
}

Andrzej Borkowski: Лабиринты дискурсов в славянских литературах эпохи барокко. Религия - политика - общество. Litteraria Sedlcensia, Colloquia, tom XVII. Siedlce: Wydawnictwo OKR[i]BL, 2015. ISSN 18971423.

Badatel z agilní polské univerzity Siedlce, která zaplavuje slavistický knižní a časopisecký trh invenčními monografiemi a studiemi, vyniká vzornou zahraniční spoluprací s řadou zemí a prominentních univerzit a řeší aktuální problémy a analyzuje tradiční artefakty, např. dílo J. A. Komenského, teorii ruské literatury, modernu a avantgardu, ruský stříbrný věk apod. (psali jsme o těchto knihách v různých periodikách, zejména Slavica litteraria a Novaja rusisti$k a$ ), přichází s fundamentálním opusem o slovanském baroku, resp. o několika diskurzech, jež se v jeho rámci v některých slovanských literaturách vedou. Text je rozdělen na tři oddíly: Náboženství, Politika, Společnost a všechny tř́i jsou zaplněny materiálem, který nám odhaluje jen určitou osu světa barokní literatury, a to středoevropsko-východoevropskou, resp. západoslovansko-východoslovanskou, nikoli už jihoslovansko-balkánskou, jež je také vcelku bohatá, když vezmeme v úvahu dalmatskou renesanci a baroko a fakt, že baroko jako univerzální styl epochy zasáhlo i východní Balkán, konkrétně Bulharsko, jak doložila česká slavistka Věnceslava Bechyňová. ${ }^{1}$ Nicméně i tento rozbor je průkazný tak, že může být - s přijetím dalších specifik - obecným obrazem barokního myšlení v slovanském literárním světě jako takovém, navíc s transcendencemi, které jsou typické pro přenos západoslovansko-východoslovanský právě polským prostřednictvím. Slovo „labyrint“ z titulu tu ovšem není náhodné. V tomto smyslu má polská literární produkce, jež ve svazku zjev-

1 BECHYŇOVÁ, Věnceslava: Barokni rysy literatury bulharských katoliků. Slavia 3, 1968; Svetlana Vasileva-Karag'ozova: Barok't v b'lgarskata literatura. Slavia 75, 2006, č. 4 , s. 407-418. ně převažuje, opravdu klíčový význam. I když je v textu zdůrazněn polský a ruský materiál, je tu přítomna i slovenská, česky psaná literatura a z české v užším slova smyslu vlastně jen Jan Amos Komenský a jeho Labyrint světa a lusthaus srdce (1. verze 1623), autor samozřejmě - přes všechny ekumenické rysy svého díla - protikatolický. Je pravda, že v české literatuře a umění obecně byla cesta baroka značně křivolaká, zejména proto, že do 19. století tu v linii Palacký - Masaryk převažoval protestantský výklad českých dějin, resp. se zdůrazňovala osa předbělohorská, i když měla své odpůrce mezi spisovateli (Jaroslav Durych a celá katolická moderna) i historiky (Josef Pekař). Byla umožněna josefínskými reformami směřujícími proti mocenskému monopolu katolické církve a také germanizací nebo odchodem většiny české šlechty po roce 1627 - ale opět se tu s vaničkou vylilo i dítě, tedy autentické české barokní texty. Teprve 20. století přináší - přes různé překážky věcné i ideologické - velké objevy českého baroka, které nebylo něčím méněcenným nebo, jak se v českém prostoru někdy říkalo, dobou temna, ale naopak dobou rozkvětu jazyka a literatury: baroko tu trvá vlastně od druhé poloviny 16 . století po - obrazně řečeno - rok 1730, často i déle, a jeho zajímavým rysem je i vznik tzv. lidového nebo pololidového baroka, tj. přizpůsobení stylu epochy lidovým představám, které vzaly baroko a jeho dominantní linie, včetně barokní erotiky představované mariánským kultem, a barokní emoci a extázi i projevy běžné zbožnosti, jako jsou tzv. boží muka dodnes zdobící vesnická rozcestí v Čechách a na Moravě, za své. ${ }^{2}$

2 KALISTA, Zdeněk: Česká barokni pout. K religiozitě čes- 
Poslední barokní slavnosti se tu konaly ve třicátých letech 18. století (např. ve Žd'áře nad Sázavou), tehdy, kdy se v Anglii rozvíjela sentimentalistická poezie. Možná by v pokračování této pečlivě napsané a analytické publikace měla mít česká literární produkce významnější místo. Z celého materiálu práce je zřejmé, že baroko, resp. barok, jako oficiální styl protireformace přerůstalo ve styl univerzální. Jeho cílem bylo vrátit do oběhu gotickou zbožnost více či méně přerušenou antropocentrismem humanismu a renesance, ale vyvolat ji bylo možné jen v emoci a extázi, ve vnitřním prožitku, nikoli jen ve vnějškové manifestaci, i když v té také, nebot i ona podporuje vznik emocí. Kataklyzmata doby, jelikož 17. století bylo poslední výspou starého světa, zasáhla celou Evropu: v Anglii to byla válka krále a parlamentu zakončená královou popravou a dočasnou dominancí puritánů, na kontinentě válka třicetiletá, ve východní Evropě, resp. Velkorusku, dynastické spory, smuta (1598-1613), války vnitřní i vnější, za nichž polsko-litevská vojska dvakrát obsadila Moskvu a dosadila tam své Lžidimitrije, zmatky občanské války a lidových povstání, stejně jako pokračující války se Švédskem. V podstatě lze říci, že v barokním období se z prostoru středověku vynořila zcela nová Evropa s novými národy a novou mentalitou a novými hodnotami, že se vlastně v důsledku takřka genocidních bojů „vyměnilo“ obyvatelstvo a přerušila se kulturní a politická kontinuita. Baroko tak zůstalo jediným scelovacím stylem celé Evropy, i když se mu tak všude neř́kalo (ve Francii se často směšovalo s klasicismem nebo se zde užívala jiná nomenklatura - s jansenisty spjatý aticismus a jezuitský asianismus -, v Anglii to byla "metaphysical poetry“ nebo „metaphysical poets“, V. Černý a Z. Kalista trvali na komparativním pojetí tzv. barokismů, tedy barokních znaků3 ${ }^{3}$. Tak to ostatně pochopil

kého lidu v době barokní. K vydání připravila, ediční poznámkou, slovníčkem, seznamem vyobrazení a závěrečnou statí doplnila Michaela Horáková. Žd’ár nad Sázavou: Cisterciana Sarensis, 2001.

3 KALISTA, Zdeněk: České baroko. Praha, 1941; týž: Tvár baroka. Praha, 1992. ĆERNÝ, V.: Soustavný přehled dějin naši vzdělanosti. Baroko a klasicismus. Jinočany, 2005; týž: i editor barokní poezie, český romanista a literární historik a kritik Václav Černý v antologii Kéż hoři popel můj (1967), který uvádí v překladech předních českých překladatelů a básníků (mj. Otokara Fischera, Františka Halase, Vladimíra Holana, Jindřicha Hořejšího, Petra Kopty, Lud'ka Kubišty, Vladimíra Mikše, Jiřího Pechara, Hany Vrbové) poezii Španělska, Portugalska, Itálie, Francie, Anglie, Německa, Čech a Moravy, Charvátska, Dubrovníku, Polska, Velkoruska, Běloruska a Ukrajiny, tedy i oblasti, jíž se říkávalo západní Rus a o jejímž zprostředkovacím významu psal Alexandr Lappo-Danilevskij. ${ }^{4}$

Také v Polsku samotném se od devadesátých let 20. století významněji než předtím rozvíjely barokistické výzkumy, včetně vztahu k českým zemím a Slezsku, které k Zemím Koruny české kdysi patřilo. ${ }^{5} \mathrm{O}$ tom, že baroko spojovalo celou kontinentální i ostrovní Evropu, svědčí i to, že překonalo všechny náboženské přehrady, i když primárně patřilo katolicismu: $\mathrm{k}$ baroku koneckonců Borkowski řadí i biskupa Jednoty bratrské J. A. Komenského, ale i pravoslavného starověrce protopopa Avvakuma Petrova a mohli bychom dodat, že $\mathrm{k}$ tradicím baroka patři i básně Johna Miltona, sekretáře pro cizí jazyky (Secretary for Foreign Tongues) při Státní

Až do předsíně nebes. Čtrnáct studii o baroku našem i cizím. Praha, 1996.

4 Viz naši recenzi na jeho reedici: Potřebná edice o ruském myšleni (Aleksandr Lappo-Danilevskij: Politische Ideen in Rußland des 18. Jahrhunderts. Istorija političeskich idej v Rossii v XVII veke v svjazi s obščim chodom razvitija kul'tury i politiki. Bausteine zur slavischen Philologie und Kulturgeschichte, Neue Folge, Bd. 1. Predislovije M. Ju. Sorokinoj. Podgotovka teksta M. Ju. Sorokinoj pri učasti K. Ju. Lappo-Danilevskogo. Böhlau Verlag, Köln - Weimar - Wien 2005). Slavica Litteraria, X 9, 2006, s. 326-327.

5 Viz naši rec.: Oživené Slezsko a staré Polsko (Dariusz Rott: Bracia czescy v dawnej Polsce. Katowice: Wydawnictwo Uniwersytetu Śląskiego, 2002. 211 s. Śląsk literacki. Materialy V sesji śląskoznawczej Pracowników Naukowych, Studentów i Gości Wydziału Filologiczego Uniwersytetu Śląskiego, Katowice 8-9 listopada 2000. Pod red. Mariana Kisiela - Barbary Morcinek-Cudak - Tomasza M. Głogowskiego. Pallas Silesia 2001. 204 s. Zbigniew Kadlubek - Dariusz Rott - Renata Ryba - Piotr Wilczek: Literatura Staropolska. Sredniowiecze - Renesans - Barok. Katowice: Wydawnictwo Uniwersytetu Ślaskiego, 2002. Opera Slavica XIII, 2003, č. 1, s. 52-53. 
radě (Council of State) první a zatím poslední anglické republiky (Commonwealth) prvního a zatím posledního anglického diktátora Olivera Cromwella. Baroko se jako červená nit vine až do naší doby, alespoň jeho jednotlivé prvky, takže k nim český katolický básník Z. Rotrekl přiřadil i písňové texty skupiny Plastic People of the Universe. ${ }^{6}$

Takto široce ovšem Borkowski baroko nechápe: jeho práce je zeširoka pojatý analytický diskurs založený na vybraných sondách do barokního literárního materiálu. V první kapitole první části o náboženství je to diskurz vnitřní metamorfózy na bázi Komenského a Kaspera Twardowského (Labyrint světa a lusthaus srdce a Łódź mtodzi z nawatności do brzegu ptynaca). Čerpá z práce slavného polského bohemisty Józefa Magnuszewského: škoda, že si nepovšiml také prací brněnského barokisty Milana Kopeckého, odborníka na celou českou starší literaturu, ${ }^{7}$ ale i další. ${ }^{8}$ Autor správně ukazuje na to, jak baroko vycházelo z gotického pojetí, jeho alegoričnosti, ale také náboženského pojetí putování, pouti ve smyslu konkrétním i přeneseném.

6 Viz ROTREKL, Zdeněk: Barokni fenomén v současnosti. Praha: TORST, 1995.

7 KOPECKÝ, Milan: K české barokní homiletice. Brno, 1968; týž: Český humanismus. Praha, 1988; týž: K české reformačni postilografii. Brno, 1970; týž: Komenský jako umèlec slova. Brno, 1992. Viz také naše recenze: Objevováni českého baroka (Žena krásná náramně. Soubor svatojanských kázání a jiných spisů z dob opata Václava Vejmluvy. Př́pravil, úvodem, doslovem a poznámkami opatřil kolektiv pod vedením Milana Kopeckého. Společnost Cisterciana Sarensis. Žd'ár nad Sázavou, 1998). Slavica Litteraria, X 2, 1999; Objevováni čského literárního baroka: skrytá výzva slavistice (Milan Kopecký: Nic stálého př́ítomného. K literárnímu baroku. Brno: Masarykova univerzita, 1999). Slavica Litteraria, X 3, 2000, s. 132-133. Viz také POSPÍŠIL, Ivo: Chudožestvennost' starinnych tekstov, Komenskij i teorija istorii literatury. In: Jan Amos Komeński w kontekście kultury i historii europejskiej XVII wieku. Jan Amos Komenský im Kontext der europäischen Kultur und Geschichte des 17. Jahrhundert. Praca zbiorowa pod redakcją naukową Babary Sitarskiej - Romana Mnicha. Sammelband unter wissenschaftlicher Leitung von Barbara Sitarska und Roman Mnich. Siedlce: Wydawnictwo Akademii Podlaskiej, 2010, s. 237-248.

8 VAŠICA, Josef: České literárni baroko: přispěvky $k$ jeho studiu. Praha, 1938; 2. vyd. 1995; týž: K dějinám staršího českého pisemnictvi. Praha, 1937; týž: Tři kapitoly o českém literárním baroku. Praha, 1933.
V druhé kapitole zkoumá mysticko-asketické prvky, mj. na Avvakumovi a Krystyně Poniatowské a dalších; zejména zajímavé je pojednání o hagiografické autobiografii Avvakuma Petrova a karmelitánky Marianny Marchocké, resp. Teresy od Jezusa (1603-1652), stejně jako o zjevení Krystyny Poniatowské a Zofie Tomické. O tom bylo už popsáno hodně papíru, ale autor je bere jako autorky literárních výtvorů, at už za nimi bylo zjevení nebo posedlost, mimořádné schopnosti nebo deviace přesahující možnosti běžné lidské psychiky. V třetí části se analyzuje Speculum magnum, jeho barokní aktualizace, jeho podoba v Polsku a jeho prostřednictvím u východních Slovanů.

Partie o politice zkoumá antiheretické spisy Petra Skargy, využívání fauny a flory, která je typickým jevem barokní poetiky, problémy prostorové a lokalizační (tělo, město, budovy, zdi apod.). $\mathrm{V}$ druhé kapitole druhé části věnované politice autor zkoumá obraz koně v politickém a panegyrickém diskursu Jana Chryzostoma Paska z Gosławic (1636-1701) od vážného symbolu až po jeho groteskní funkci. V souvislosti $\mathrm{s}$ třetí kapitolou spojenou s válkami $\mathrm{s}$ Tatary a Turky, mj. u Wacława Potockého (1625-1696) a Łazarze Baranowicze (1593-1694), pravoslavného duchovního a antijezuitského bojovníka, tu je scelovací funkce baroka více než zjevná. Osobitým problémem zůstává rytîrstvo a rytîrství jako ryze středověká kategorie, vrcholící v gotice a skomírající v renesanci, v baroku se oživující, ale v jiném, spíše stylizačním kontextu: zejména u východních Slovanů je spíše „exotikou“ pronikající sem z převážně německého Pobaltí: Velkorusové rytîrstvo ani jeho kulturní tradici v podstatě neměli, najdeme tam spíše etiketní nebo obecně kulturní ohlasy a reflexe.

Třetí kapitola věnovaná společnosti začíná antižidovským barokním diskurzem, jenž by mohl být výrazněji spojen s tradicí antisemitismu středověkého, ale i renesančního a později klasicistického, jak ho známe z německých univerzit 18. století. Ukazuje se, že v baroku se koncentrovala, zauzlila problematika, v níž bylo pokračováno, často až do tragických konců de facto do současnosti. Výrazná je kapitola 
o naučných publikacích. Vše vrcholí kataklyzmatickými a katastrofickými momenty baroka, jimiž se tato epocha jakoby symbolicky uzavírá. Jestliže se naše doba někdy nazývá podle Nikolaje Berd’ajeva novým středověkem, jenž je nepochybně spojen s barokem, je dnešní výskyt katastrof, neznámých nemocí připomínajících morové rány nebo cholerové pandemie a větší či menší př́rodní kataklyzmata zajímavým ontickým signálem. Tyto katastrofy sleduje Borkowski v literárních textech na popisech požárů, záplav a zemětřesení, z nichž to lisabonské ukázané zde na česky psané básni Slováka Jana/ Jána Černianského Žalostné vypsání pádu a vyvrácení města Lizbony (1756) bylo pozdní symbolickou tečkou za celým barokem.

Téma barokních diskurzů demonstrované na náboženství, politice a společnosti vede i k zamyšlení nad konci epoch, nad novými křižovatkami: nikoli nadarmo v nynější době se k baroku i k jeho katastrofickému literárnímu diskurzu často vracíme.

Práce Andrzeje Borkowského je dobře napsána, má přehlednou strukturu, čerpá z řady podnětů a materiálů spjatých i s autorovými studijními cestami a pobyty po místech, kde analyzovaná díla vznikala. Práce je psána rusky, ale využívá primární i sekundární literatury v různých jazycích: ruské, polské, ukrajinské, české, slovenské ad., dostává se typově i k literatuře západní Evropy, sice stopově, ale průkazně a funkčně, v pozadí se znalostí tradice antické, středověké a renesanční. Co je ještě hodno zaznamenání: text je v podstatě bez pravopisných chyb, jimiž se v spisech pracujících s různými jazyky jen hemží; to třeba kvitovat a ocenit.

To, co by možná bylo záhodno posílit, je vědomí baroka jako scelení, zauzlení, vývojové křižovatky ukazující do různých směrů, tedy i jeho sepětí s předcházejícími kulturními epochami. Nikoli nadarmo mluvil český slavista zahajující svou univerzitní dráhu v Bratislavě Frank Wollman (1888-1969) o celistvosti renesančně humanisticko-reformačně barokní: nakonec i uváděný prríklad Královny víl (The Faerie Queene) Edmunda Spensera, sám Shakespeare, resp. Jan Kochanowski patři k jasně profilovaným autorům, v jejichž díle se všechny tyto podněty prolínají. ${ }^{9}$
9 Viz také naše studie a recenze: Barokni literatura z pohledu komparativně genologické slavistiky. K barokologickým studiim Milana Kopeckého. Slavia 1998, roč. 67, seš. 3, s. 349-356. Mladá slovakistika: nově i tradičně, pružnĕ a kreativně (Vojtech, M.: Od baroka k romantizmu. Literárne smery a tendencie v slovenskej literatúre v rokoch 1780-1840. Univerzita Komenského. Bratislava 2003). Opera Slavica, XIV., 2004, č. 1, s. 57-58. Baroko jako vývojový problém literatury (Problém slovanských literatur). In: Slovenský literárny barok. Venované 340 . výročiu smrti Petra Benického. Univerzita Komenského, Bratislava 2005, s. 180-188. Baroko jako historicky vymezený fenomén a jako kulturni typ (Barokový slavizmus Milana Kopeckého a publicistika Jaroslava Durycha). In: Pons Strigoniensis. Studia. Nové interpretace českého baroka. A Cseh barokk új interpretrációi. Sborník z mezinárodní konference, Piliscsaba, 12.-13. května 2003. Nemzetközi konferencia, Piliscsaba, 2003. május 12-13. Pázmány Péter Katolikus Egyetem, Esztergom - Piliscsaba 2004, s. 11-24. Barokni poetika a ideologie (Sivia Lauková: Sondy do barokovej literatúry. Univerzita Konštantína Filozofa, Filozofická fakulta, Nitra 2009). Slavica Litteraria X 13, Barok2010/1-2, s. 144. 